\title{
Determination of Significant Pretreatment Factors that Predict Survival in Indonesian Subjects with Breast Cancer
}

\author{
Citra Aryanti $^{1 *(\mathbb{D})}$, Putu Anda Tusta Adiputra ${ }^{2}$ (D) Tjokorda GB Mahadewa $^{3}$, Sri Maliawan ${ }^{3}$ (i) I. N. W. Steven Christian ${ }^{2}$, \\ Ida Bagus Made Suryawisesa ${ }^{2}$ \\ ${ }^{1}$ Department of Surgery, Udayana University, Sanglah General Hospital, Denpasar, Bali, Indonesia; ${ }^{2}$ Department of Surgery, \\ Division of Surgical Oncology, Udayana University, Sanglah General Hospital, Denpasar, Bali, Indonesia; ${ }^{3}$ Department of \\ Neursurgery, Division of Surgical Oncology, Udayana University, Sanglah General Hospital, Denpasar, Bali, Indonesia
}

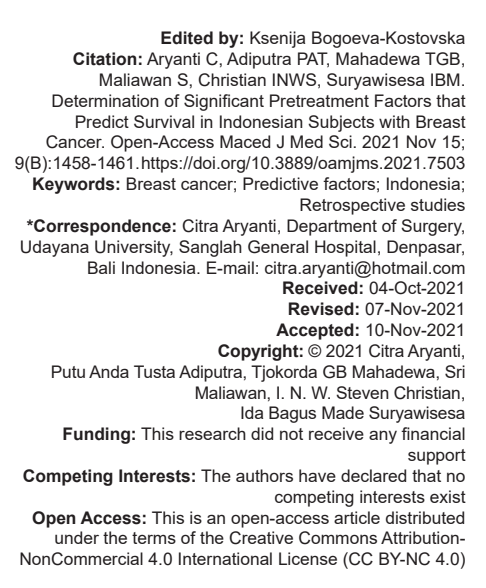

Introduction

Breast cancer is still showing high morbidity and mortality in the world. Worldwide, data showed that breast cancer accounts for $23 \%$ of all cancer cases and occupies the second position as a cause of death with a mortality rate of $14 \%$ [1]. In Indonesia, breast cancer is the most prevalent cancer in women, surpassing the cases of cervical and lung cancer [2].

Many factors are important in determining the progression of breast cancer, such as demographic, clinical, pathological, and molecular factors. Various studies have shown that ethnicity has a great influence, thus determining risk factors should be specified in each population [3]. However, the previous studies were mostly conducted in Western countries which only a few studies were taking population in Southeast Asia. Thus, this study aimed to determine the significant pretreatment factors that predict survival in Indonesian subjects with breast cancer.

\section{Methods}

\section{Study design}

This was a cohort retrospective study conducted on breast cancer subjects visiting Sanglah General Hospital from 2016 to 2020. This research was conducted after obtaining a research permit and obtaining approval from the local ethics committee. The diagnosis of breast cancer has been histopathologically confirmed. Data were taken from the medical records of the Bali Cancer Registry.

\section{Population of this study}

This study included all subjects visiting the Sanglah General Hospital before December 2020. Inclusion criteria were the female subjects with breast cancer and histopathologically confirmed to have breast cancer from the biopsy specimen. Exclusion criteria were the presence of missing data, had other 
malignancy or immunodeficiency disease. In this study, 150 subjects were taken from each group by taking into account the 13 variables studied as prognostic factors, which the required sample is at least 10 times the number of variables studied. When added with consideration of $10 \%$ bias, the minimum number of samples required is 143 samples 150 samples.

\section{Data collection}

Demographic (age), clinical (tumor size, lymph node, metastases, Karnofsky score, and serum CA15-3 levels), and pathological (hormone receptor, human epidermal growth factor receptor 2, and Ki67) data were collected. The main parameter was survival, defined as the time from diagnosis to death. Age was classified as $40-60$ years old, $<40$ or $>60$ years old with the consideration of $40-60$ years as the predilection age for breast cancer. Karnofsky score was classified with the cutoff point of 70 , based on the optimal performance status to receive treatment or carry out normal activity. Tumor size, lymph node, and metastasis were classified based on the criteria in tumor, node, and metastasis classification of malignant tumors by the UICC and the AJCC Cancer Staging Manual. For CA15-3 level, we used the cutoff point of $25 \mathrm{lU} / \mathrm{mL}$ based on the cut point in our institution laboratory. The status of lymphovascular invasion and tumor-infiltrating lymphocytes was obtained from histopathology results of the biopsy. Histological grade was assessed using the Nottingham Grading System. The molecular status of estrogen receptor, progesterone receptor, HER2, and Ki67 was determined by immunohistochemistry.

\section{Data analysis}

All statistical analyses were performed using SPSS software (version 24.0; SPSS Inc., Chicago, IL, USA). Numerical data were in standard deviation while categorical variables are expressed in terms of frequency and percentage. Median survival was determined by the Kaplan-Meier method. Cox proportional hazard regression model with a $95 \% \mathrm{Cl}$ confidence limit was conducted to assess the hazard ratio.

\section{Results}

A total of 150 survived and 150 died breast cancer subjects were included in this study. All data were collected before the patient underwent chemotherapy, mastectomy surgery, or radiotherapy. Most subjects in this study aged $40-60$ years $(75.3 \%)$, had a Karnofsky score of more than $70(86.7 \%)$, tumor size larger than $5 \mathrm{~cm}$ but no infiltration (43.3\%) had enlarged lymph nodes lymph node (48.0\%), no metastases (73.\%), positive hormonal receptor $(60 \%)$, HER2 receptor +1 (45.3\%), Ki67 more than 14\% (66\%), Iymphovascular invasion positive (55\%), tumor-infiltrating lymphocytes +1 (49\%), non-special pathological type (82.3\%), and histological grade 2 (50\%) (Table 1).

The median survival of Indonesian subjects with breast cancer was 47 months with a standard deviation of 4.851 (Figure 1). Majority of breast cancer subjects with mortality outcome were those who had Karnofsky score less than 70 (HR 0.14, $p<0.001)$, tumor size $\geq 5 \mathrm{~cm}$ with infiltration (HR 2.11, $p<0.001$ ), presence of contralateral lymph node (HR 2.54, $p<0.001)$, with metastasis (HR 6.38, $p<0.001)$, serum CA15-3 level $>25 \mathrm{IU} / \mathrm{mL}$ (HR 4.29, $\mathrm{p}<0.001)$, negative hormonal receptor (HR 2.26, p < 0.001), negative HER2 receptor (HR 0.82, p < 0.001), Ki67 higher than 14 (HR 1.98, $p<0.001$ ), negative lymphovascular invasion (HR 2.52, $p<0.001)$, negative tumor-infiltrating lymphocytes (HR 0.65, $p=0.001$ ), and histological Grade 3 (HR 2.35, $p<0.001)$. Age and pathological type were not significantly differed the breast cancer outcome.

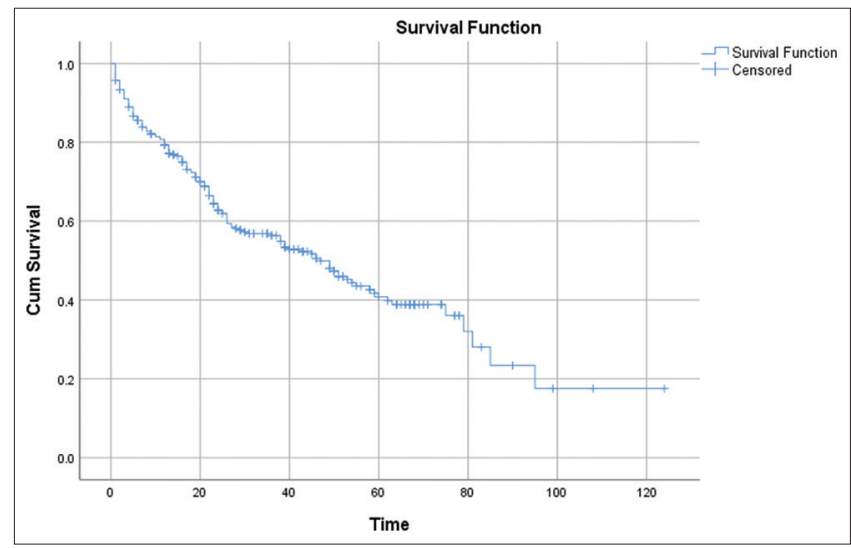

Figure 1: Kaplan-Meier curve of survival

\section{Discussion}

Early diagnosis of breast cancer would allow a great impact in improving breast cancer survival. Thus, it is important to know the survival predictor factors early as information to patients and the basis for clinicians to consider further treatment modalities. In this study, there was no significant effect of age on survival, it could be because the majority of patients in this study were diagnosed at the age of 40-60 years. In addition, $70 \%$ of the histopathological examination results were non-special pathological types. This could be a factor that causes statistical analysis not to show a significant association between pathological type and breast cancer survival.

Tumor size, enlarged lymph nodes, and metastases to other organs had been recognized as major factors associated with breast cancer 
Table 1: Characteristics of subjects in this study

\begin{tabular}{|c|c|c|c|c|c|c|}
\hline Data & Survived (\%) & Died (\%) & Total $(\mathrm{n})$ & Percentage (\%) & $p$ & $\mathrm{HR}(95 \% \mathrm{Cl})$ \\
\hline \multicolumn{7}{|l|}{ Age (years old) } \\
\hline$<40$ & 6.0 & 4.7 & 32 & 10.7 & \multirow[t]{3}{*}{0.426} & 1.00 \\
\hline $40-60$ & 36.0 & 39.3 & 226 & 75.3 & & $0.731-1.38$ \\
\hline$>60$ & 8.0 & 6.0 & 42 & 14.0 & & \\
\hline \multicolumn{7}{|l|}{ Karnofsky score } \\
\hline$\geq 70$ & 47.7 & 39.0 & 260 & 86.7 & \multirow{2}{*}{$<0.001$} & 0.14 \\
\hline$<70$ & 2.3 & 11.0 & 40 & 13.3 & & $0.09-0.21$ \\
\hline \multicolumn{7}{|l|}{ Tumor size } \\
\hline$<2 \mathrm{~cm}$ & 1.3 & 0 & 4 & 1.3 & \multirow[t]{4}{*}{$<0.001$} & 2.11 \\
\hline $2-5 \mathrm{~cm}$ & 15.0 & 5.7 & 62 & 20.7 & & $2.15-3.53$ \\
\hline$\geq 5 \mathrm{~cm}$ & 26.7 & 16.7 & 130 & 43.3 & & \\
\hline Infiltration & 7.0 & 27.7 & 104 & 34.7 & & \\
\hline \multicolumn{7}{|l|}{ Lymph node } \\
\hline Negative & 22.3 & 7.0 & 88 & 29.3 & \multirow[t]{3}{*}{$<0.001$} & 2.54 \\
\hline Ipsilateral & 23.0 & 25.0 & 144 & 48.0 & & $2.005-3.22$ \\
\hline Contralateral & 4.7 & 18.0 & 68 & 22.7 & & \\
\hline \multicolumn{7}{|l|}{ Metastasis } \\
\hline No & 47.0 & 26.0 & 219 & 73.0 & \multirow[t]{2}{*}{$<0.001$} & 6.38 \\
\hline Yes & 3.0 & 24.0 & 81 & 27.0 & & $4.55-8.95$ \\
\hline \multicolumn{7}{|c|}{ Serum CA15-3 level } \\
\hline$<25 \mathrm{IU} / \mathrm{mL}$ & 44.0 & 26.0 & 210 & 70.0 & \multirow[t]{2}{*}{$<0.001$} & 4.29 \\
\hline$>25 \mathrm{IU} / \mathrm{mL}$ & 6.0 & 24.0 & 90 & 30.0 & & $3.03-5.87$ \\
\hline \multicolumn{7}{|c|}{ Hormonal receptor (ER/PR) } \\
\hline Negative & 15.7 & 24.3 & 120 & 40.0 & \multirow[t]{2}{*}{$<0.001$} & 2.26 \\
\hline Positive & 34.3 & 25.7 & 180 & 60.0 & & $1.6-3.09$ \\
\hline \multicolumn{7}{|l|}{ HER2 receptor } \\
\hline Negative & 8.0 & 13.0 & 63 & 21.0 & \multirow[t]{4}{*}{$<0.001$} & 0.82 \\
\hline+1 & 24.7 & 20.7 & 136 & 45.3 & & $0.67-0.99$ \\
\hline+2 & 9.0 & 14.7 & 71 & 23.7 & & \\
\hline+3 & 8.3 & 1.7 & 30 & 10.0 & & \\
\hline \multicolumn{7}{|l|}{ Status Ki67 } \\
\hline$<14 \%$ & 19.3 & 14.7 & 102 & 34.0 & \multirow[t]{2}{*}{$<0.001$} & 1.98 \\
\hline$>14 \%$ & 30.7 & 35.3 & 198 & 66.0 & & $1.32-2.75$ \\
\hline \multicolumn{7}{|l|}{ LVI } \\
\hline Positive & 34.0 & 21.0 & 165 & 55.0 & \multirow[t]{2}{*}{$<0.001$} & 2.52 \\
\hline Negative & 16.0 & 29.0 & 135 & 45.0 & & $1.8-3.51$ \\
\hline \multicolumn{7}{|l|}{ TIL } \\
\hline Negative & 7.7 & 15.7 & 70 & 23.3 & 0.001 & 0.65 \\
\hline+1 & 24.3 & 24.7 & 147 & 49.0 & & $0.53-0.81$ \\
\hline+2 & 15.0 & 8.3 & 70 & 23.3 & & \\
\hline+3 & 3.0 & 1.3 & 13 & 4.3 & & \\
\hline Pathological typ & & & & & & \\
\hline Lobular & 10.0 & 7.3 & 52 & 17.3 & 0.261 & 0.774 \\
\hline $\begin{array}{l}\text { Non-special } \\
\text { type }\end{array}$ & 40.0 & 42.7 & 247 & 82.3 & & $0.49-1.22$ \\
\hline Grade & & & & & & \\
\hline 1 & 7.3 & 0.7 & 24 & 8.0 & $<0.001$ & 2.35 \\
\hline 2 & 27.7 & 22.3 & 150 & 50.0 & & $1.75-3.15$ \\
\hline 3 & 15.0 & 27.0 & 126 & 42.0 & & \\
\hline
\end{tabular}

prognosis [4]. In this study, it was also found that patients who had enlarged lymph nodes and organ metastases were associated with lower survival. Performance status can represent the functional condition or physical fitness status of the patient at that time, of which our study is consistent with previous reports CA15-3, widely expressed in breast epithelial, was the best and most widely used serum marker [5]. In this study, a significant effect was found between CA15-3 levels and breast cancer survival.

The role of hormonal receptor assays was first studied more than 30 years ago. It is known that the presence of the hormonal receptor in tumors allows hormonal therapy with an $80 \%$ response [6]. In addition, the presence of HER2 receptor expression in breast cancer is also related to a better prognosis because of the availability of targeted therapy with trastuzumab. $\mathrm{Ki}-67$, a proliferative marker, increased along with the level of proliferation [7]. This study also supported that the higher the Ki67 value, the more breast cancer progression, so the survival will be lower.

Lymphovascular invasion was associated with a threefold higher mortality rate [8]. In this study, it was also found that was associated with lower survival rates.
Tumor-infiltrating lymphocytes, reflecting the ability of host immune system, was associated with better survival [9]. Assessment of histological grade, a combination of tubular differentiation, nucleus/cytoplasm, and mitotic activity, is an important component in the assessment of the histological grade of breast cancer [10]. In this study, it was also shown that the higher the histological grade of breast cancer cells, the lower the survival prognosis.

\section{Conclusion}

Breast cancer subjects who had better survival were patients with small tumor size, no lymph node enlargement, no organ metastases, Karnofsky score more than 70 , serum CA15-3 levels less than $25 \mathrm{IU} / \mathrm{mL}$, hormone receptor positive, HER2 receptor positive, low Ki67 status, negative lymphovascular invasion, low histological grade, and high tumorinfiltrating lymphocytes. Thus, the more risks were present, the more aggressive therapy should be considered along with better counseling to the patient. 
There were significant effects of tumor size, KGB status, metastasis, serum CA15-3 levels, hormone receptor, HER2 receptor, Karnofsky score, lymphovascular invasion, tumor-infiltrating lymphocytes, and histological grade to breast cancer subjects' survival.

\section{Ethical Approval}

This study has been approved by the Local Ethical Committee (973/UN14.2.2.VII.14/LT/2020).

\section{Acknowledgments}

The authors acknowledged the Division of Digestive Surgery, Department of Surgery, Denpasar, Bali, Indonesia, which have given a support for this study.

\section{Data Availability}

The data used in this paper are available from the corresponding author on reasonable request.

\section{References}

1. Sung H, Ferlay J, Siegel R, Laversanne M, Soerjomataram I, Jemal A, et al. Global Cancer Statistics 2020: GLOBOCAN estimates of incidence and mortality worldwide for 36 cancers in 185 countries. CA Cancer J Clin. 2021;71(3):209-49. http://doi. org/10.3322/caac.21660

PMid:33538338

2. Kementrian Kesehatan RI. Beban Kanker di Indonesia Kementrian Kesehatan RI: Pusat Data dan Informasi; 2019.

3. Gail MH, Brinton LA, Byar DP, Corle DK, Green SB, Schairer C, et al. Projecting individualized probabilities of developing breast cancer for white females who are being examined annually. J Natl Cancer Inst. 1989;81(24):1879-86. http://doi.org/10.1093/ jnci/81.24.1879

PMid:2593165

4. Sopik T, Narod SA. The relationship between tumour size, nodal status, and distant metastases: on the originis of breast cancer. Breast Cancer Res Treat. 2018;170(2):647-56. http:// doi.org/10.1007/s10549-018-4796-9

PMid:29693227

5. Chu WG, Ryu DW. Clinical significance of serum CA15-3 as a prognostic parameter during follow-up periods in patients with breast cancer. Ann Surg Treat Res. 2016;90(2):57-63. http://doi. org/10.4174/astr.2016.90.2.57

PMid:26878012

6. Bardou VJ, Arpino G, Elledge RM, Osborne CK, Clark GM Progesterone receptor status significantly improves outcome prediction over estrogen receptor status alone for adjuvant endocrine therapy in two large breast cancer databases. J Clin Oncol. 2003;21(10):1973-9. http://doi.org/10.1200/ JCO.2003.09.099

PMid:12743151

7. Ning J, Fouad TM, Lin H, Sahin AA, Lucci A, Woodward WA, et al. The impact of $\mathrm{Ki}-67$ in the context of multidisciplinary care in primary inflammatory breast cancer. J Cancer. 2019;10(12):2635-42. http://doi.org/10.7150/jca.32453

PMid:31258771

8. Zhang S, Zhang D, Gong M, Wen L, Liao C, Zou L. High lymphatic vessel density and presence of lymphovascular invasion both predict poor prognosis in breast cancer. BMC Cancer 2017;17(1):335. http://doi.org/10.1186/s12885-017-3338-x PMid:28514957

9. Wang K, Xu J, Zhang T, Xue D. Tumor-infiltrating lymphocytes in breast cancer predict the response to chemotherapy and survival outcome: A meta-analysis. Oncotarget. 2016;7(28):44288-98. http://doi.org/10.18632/oncotarget.9988 PMid:27329588

10. Makki J. Diversity of breast carcinoma: Histological subtypes and clinical relevance. Clin Med Insights Pathol. 2015;8:23-31. http://doi.org/10.4137/CPath.S31563

PMid:26740749 